\title{
Correlation between Expulsion of Distal Ureteric Calculus with CRP Level, WBC Count and Neutrophil Percentage among the Patients attending on Manipal Teaching Hospital, Pokhara (Retrospective Study)
}

\author{
Timilsina BD ${ }^{1}$, Karki OB ${ }^{1}$, Subedi B $^{2}$ \\ ${ }^{1}$ Department of Surgery, Manipal Teaching Hospital, Pokhara, Nepal \\ ${ }^{2}$ Pokhara Academy of Health Science, Pokhara, Nepal
}

Received: July 18, 2020

Accepted: November 25, 2020

Published: December 30, 2020

Cite this paper:

Timilsina BD, Karki OB, Subedi B. Correlation between Expulsion of Distal Ureteric Calculus with CRP Level, WBC Count and Neutrophil Percentage among the Patients attending on Manipal Teaching Hospital, Pokhara (Retrospective Study). Nepal Journal of Medical Sciences 2020;5(1):26-31. http://dx.doi.org/10.3126/njms. v5i1.36708

\begin{abstract}
Introduction: Urolithiasis is a common medical diagnosis that doctor encounters in the outpatients and emergency departments. The prevalence of renal stone disease has increased steadily over the past decades. There are different modalities of treatment of ureteric calculus. However, most of the distal ureteric calculus passes spontaneously thus the application of invasive procedure at the early stage can be considered overtreatment.

Methods: The 68 patients of the surgical department, Manipal teaching hospital, Pokhara, with distal ureteric calculus of $\leq 8 \mathrm{~mm}$, who were under the treatment Tamsulosin Hydrochloride $0.4 \mathrm{mg}$ once daily for 2 weeks or till the expulsion of stone from 1st October 2017 to 30th September 2018 (one year period) were retrospectively evaluated for the spontaneous stone expulsion rate and its association with serum CRP level, WBC count and Neutrophil percentage. The patients were divided into 2 groups i.e. spontaneously ureteric stone expelled group and non expelled group. Furthermore, for statistical analysis, each group were subdivided according to normal and elevated serum CRP level, white blood cell count and neutrophil percentage. The associations between these factors and ureteral stone passage were then examined.
\end{abstract}

Results: Most of the cases were in the age group of 21-40 years with the mean age of $40.09 \pm$ 16.11, where $57.4 \%$ of patients were male. Among all mean duration of symptoms was 6 days. The ratio of left to right stone was $1.26: 1$. Out of 68 patients, $80.9 \%$ of the patient's distal ureteric stone was passed out spontaneously with medical expulsion therapy. There were statistically significant $(\mathrm{p}<0.001)$ association between normal serum CRP level, White cell counts and neutrophil percentage with the expulsion of distal ureteric calculus with size $\leq 8 \mathrm{~mm}$.

Conclusion: There is a higher expulsion rate of distal ureteric calculus of size $\leq 8 \mathrm{~mm}$ with the patient of the normal level of serum CRP level, White cell counts and neutrophil percentage than that of abnormal level.

Keywords: C-reactive protein; Distal Ureteric Calculus; Neutrophil Percentage; Stone Expulsion Correspondence to: Dr Bishwo Deep Timilsina

Department of Surgery

Manipal Teaching Hospital, Pokhara, Nepal

Email: deepbishow@hotmail.com

Licensed under CC BY 4.0 International License which permits use, distribution and reproduction in any medium, provided the original work is properly cited 


\section{INTRODUCTION}

Renal colic with calculi is the most common cause of a patient visit to the hospital. It affects $8-15 \%$ of the world population. ${ }^{1}$ Ureteric stone accounts for $20 \%$ and almost $70 \%$ of these are distal ureteric stones. ${ }^{2}$ Ureteric colic influences patients quality of life causing pain and distress and adding significant economic burden, thus emphasizing the importance of meticulous management of the disease is paramount. $^{3}$

Most of the distal ureteric stone passes spontaneously thus application of invasive procedure at an early stage can be considered overtreatment adding unnecessary economic burden., ${ }^{4,5}$ If predictive factors could be identified for whether the spontaneous passage of ureteral stone can be expected, it would help select the treatment method.

Some of the studies were carried out to identify the predictors, though various results have been found..$^{6,7,8,9}$ Thus this study was conducted to analyze the predictors of spontaneous expulsion of distal ureteric calculus.

\section{METHODS}

A cross-sectional retrospective study was carried out from the medical records of the 93 patients presented with distal ureteric stones size $\leq 8 \mathrm{~mm}$ from 1st October 2017 to 30th September 2018 in Manipal Teaching Hospital, only after approval from the institutional review board (IRB No. MEMG/IRC/250/ GA), of which only 68 patients fulfilled the inclusion criteria

So a total of 68 patients who fulfilled the inclusion criteria during the study period were enrolled on the study. The patients were under the treatment of Tamsulosin Hydrochloride $0.4 \mathrm{mg}$ once daily for 2 weeks or until the expulsion of distal ureteric calculi.

Patient with proximal or middle ureteric calculus, multiple ureteric calculi, moderate to severe hydroureteronephrosis, malignancy, chronic renal insufficiency, pyonephrosis, under steroids and oral contraceptive pills were excluded.

For statistical analysis, each group were subdivided according to normal and elevated serum CRP level, white blood cell count and neutrophil percentage. The associations between these factors and ureteral stone passage were then examined.

Statistical analysis was performed using SPSS statistical software, version 21.0. Mean, Standard Deviation (SD), number and percentage were calculated for descriptive analysis. Bivariate analysis was done by using student $\mathrm{t}$-test for continuous variable and chisquare test for categorical variables to compare between two groups of spontaneous expulsion of stone. A p-value of $<0.05$ was considered significant.

\section{RESULTS \\ General characteristics:}

The age of the patients with distal ureteric calculus ranged from 18 to 83 years with a mean age of $40.09 \pm 16.11$ years (mean $\pm S D$ ). Most of the patients were in the age group of 21 to 40 years $41(60.3 \%)$, among which 39 (57.4\%) were males and $29(42.6 \%)$ were females with a male to female ratio of 1.34:1.

\section{Characteristics of stone:}

Among 68 patients, stone size ranged from 3 to $8 \mathrm{~mm}$. The mean stone size was $5.78 \mathrm{~mm}$. The duration of the patient presenting with symptoms of ureteric colic ranges from 1 to 21 days. The mean duration of symptoms was 6 days. Thirty-eight patients (55.9\%) had stone on the left ureter while thirty patients (44.1\%) had stone on the right ureter. The ratio of left to right was $1.26: 1$.

\section{Spontaneous expulsion of the distal ureteric calculus with medical expulsion therapy:}

Out of 68 patients, 55 (80.9\%) spontaneously passed their stone with medical expulsion therapy while $13(19.1 \%)$ did not pass the stone. The remaining 13 cases were suggested for Ureteroscopic Lithotripsy (URSL) or Extracorporeal Shock Wave Lithotripsy (ESWL).

The cumulative stone-passage rate was 14 (25.5\%), 25 (45.5\%), 13 (23.6\%) and 3 (5.4\%) at $1-4,5-8,9-12$ and $>12$ days after starting the 
medical expulsion therapy, respectively. The mean duration of expulsion was 6.91 days. Spontaneous expulsion of the distal ureteric stone with medical expulsive therapy was $21(100 \%), 20(90.9 \%), 8(88.9 \%)$ and $6(37.5 \%)$ for stones measuring $1-5 \mathrm{~mm}, 5.1-6 \mathrm{~mm}, 6.1-$ $7 \mathrm{~mm}, 7.1-8 \mathrm{~mm}$ in width, respectively.

Table 1: Relationship of Spontaneous expulsion of the distal ureteric calculus with medical expulsion therapy according to size

\begin{tabular}{ccccc} 
Size of $\begin{array}{c}\text { Spontane- } \\
\text { ous } \\
\text { stone } \\
\text { expulsion } \\
(+)(\%)\end{array}$ & $\begin{array}{c}\text { Spontaneous } \\
\text { expulsion } \\
(-)(\%)\end{array}$ & $\begin{array}{c}X^{2} \\
\text { value }\end{array}$ & p-value \\
$\leq 5 \mathrm{~mm}$ & $21(100)$ & $0(0)$ & & \\
$5.1-8$ & $34(72.3)$ & $13(27.7)$ & 7.181 & $\mathbf{0 . 0 0 7}$ \\
$\mathrm{mm}$ & $3(72)$ & & \\
\hline
\end{tabular}

Table 2: Relationship of spontaneous expulsion of stone with white blood cell count

\begin{tabular}{|c|c|c|c|}
\hline WBC (cells/cc) & $\begin{array}{l}\text { Spontaneou } \\
\text { expulsion } \\
(+)(\%)\end{array}$ & $\begin{array}{l}\text { Spontane- } \\
\text { ous expul- } \\
\text { sion }(-)(\%)\end{array}$ & $\underset{\text { value }}{X^{2}}$-value \\
\hline $\begin{array}{l}\text { Normal } \\
(4000-11000)\end{array}$ & $51(92.7)$ & $4(7.3)$ & $26.10<\mathbf{0 . 0 0 1}$ \\
\hline $\operatorname{High}(>11000)$ & $4(30.8)$ & $9(69.2)$ & \\
\hline
\end{tabular}

Table 3: Relationship of spontaneous expulsion of stone with neutrophil percentage

\begin{tabular}{|c|c|c|c|c|}
\hline $\begin{array}{c}\text { Neutrophil } \\
\text { percentage } \\
(\%)\end{array}$ & $\begin{array}{l}\text { Spontane- } \\
\text { ous } \\
\text { expulsion } \\
(+)(\%)\end{array}$ & $\begin{array}{c}\text { Spon- } \\
\text { taneous } \\
\text { expul- } \\
\text { sion (-) } \\
(\%)\end{array}$ & $\begin{array}{c}X^{2} \\
\text { value }\end{array}$ & P-value \\
\hline $\begin{array}{l}\text { Normal } \\
(50-75)\end{array}$ & $51(96.3)$ & $2(3.7)$ & \multirow[t]{2}{*}{36.58} & \multirow[t]{2}{*}{$<0.001$} \\
\hline High (>75) & $4(26.7)$ & $11(73.3)$ & & \\
\hline
\end{tabular}

Table 4 : Relationship of spontaneous expulsion of the stone with CRP level

\begin{tabular}{|c|c|c|c|c|}
\hline $\begin{array}{c}\text { CRP } \\
(\mathrm{mg} / \mathrm{L})\end{array}$ & $\begin{array}{c}\text { Spontaneous } \\
\text { expulsion }(+) \\
(\%)\end{array}$ & $\begin{array}{l}\text { Spon- } \\
\text { taneous } \\
\text { expulsion } \\
(-)(\%)\end{array}$ & $\begin{array}{c}X^{2} \\
\text { value }\end{array}$ & P-value \\
\hline $\begin{array}{l}\text { Nor m a l } \\
(\leq 6)\end{array}$ & $47(92.1)$ & $4(7.9)$ & \multirow[t]{2}{*}{16.77} & \multirow[t]{2}{*}{$<0.001$} \\
\hline $\operatorname{High}(>6)$ & $8(47.1)$ & $9(52.9)$ & & \\
\hline
\end{tabular}

There is a statistically significant association ( $\mathrm{p}<0.001$ ) between normal CRP level, neutrophil percentage and WBC count with the spontaneous expulsion of distal ureteric calculus but not with the stone size ( $\mathrm{p}=0.007)$.

Table 5: Comparison of patient characteristics according to the success of spontaneous expulsion of distal ureteric

stone

\begin{tabular}{|c|c|c|c|}
\hline Characteristics & $\begin{array}{l}\text { Spontaneous } \\
\text { expulsion }(+)\end{array}$ & $\begin{array}{l}\text { Spontaneous } \\
\text { expulsion (-) }\end{array}$ & p-value \\
\hline $\begin{array}{l}\text { Number of } \\
\text { patients (n) }\end{array}$ & 55 & 13 & \\
\hline Age (years) & $40.58 \pm 17.23$ & $38.00 \pm 10.38$ & 0.412 \\
\hline Male/Female & $34 / 21$ & $5 / 8$ & \\
\hline $\begin{array}{l}\text { Left/Right } \\
\text { CRP(mg/L) }\end{array}$ & $33 / 22$ & $5 / 8$ & $\begin{array}{c}0.160 \\
<0.001\end{array}$ \\
\hline Normal $(\leq 6)$ & 92 & 6 & \\
\hline $\operatorname{High}(>6)$ & 20 & 25 & \\
\hline $\begin{array}{l}\text { White cell count } \\
\text { (cells/cc) }\end{array}$ & 51 & 4 & $<0.001$ \\
\hline $\begin{array}{l}\text { Normal (4000- } \\
11000) \\
\text { High }(>11000)\end{array}$ & 4 & 9 & \\
\hline $\begin{array}{l}\text { Neutrophil per- } \\
\text { centage }(\%)\end{array}$ & 51 & 2 & $<0.001$ \\
\hline $\begin{array}{l}\text { Normal } \\
(50-75) \\
\operatorname{High}(>75)\end{array}$ & 4 & 11 & \\
\hline \multicolumn{4}{|c|}{$\begin{array}{l}\text { There were no significant differences between } \\
\text { age, gender and side of the stone (p-value } \\
0.412,0.126,0.160 \text { ) respectively. Significant } \\
\text { differences were present in CRP level, } \\
\text { neutrophil percentage and WBC count. } \\
\text { Patients with distal ureteric stone } \leq 8 \mathrm{~mm} \\
\text { with normal CRP level, normal white cell } \\
\text { count and normal neutrophil percentage had }\end{array}$} \\
\hline
\end{tabular}


high chances of spontaneous expulsion with medical expulsion therapy.

\section{DISCUSSION}

Lifetime prevalence of ureteric stone is 10 to $15 \% .7$ Conservative management with medical expulsion treatment because of spontaneous expulsion of distal ureteric stone together with the use of minimally invasive treatment with ESWL, URSL and Open/ Laparoscopic removal of ureteric stone are various treatment modalities that exists depending upon the stone size, location and character of the stone. Advancement in minimally invasive techniques and their high success rate has resulted in its wide adoption for the treatment of ureteric stone. ${ }^{10}$

Despite a higher success rate in the removal of ureteric stones with minimally invasive techniques, their disadvantages lie in their higher operating cost and complications. Distal ureteric stones which have higher chances of spontaneous expulsion can also be managed conservatively. However, they are also related to fewer complications thus making the decision to treat distal ureteric calculus with either treatment difficult. There is still no clear guidelines regarding the selection of patients for either treatment. Various factors such as CRP, WBC count, Neutrophil percentage which could predict the spontaneous expulsion of stone have not been much studied; therefore this study was conducted to determine predictors of spontaneous expulsion of distal ureteric calculus up to $8 \mathrm{~mm}$ with due consideration with CRP, WBC count, Neutrophil percentage. A total of 68 patients were retrospectively included in this study.

The age of the patients in this study ranged from 18 to 83 years with a mean age of $40.09 \pm 16.11$ years (mean \pm SD). Most of the patients were in the age group 21 to 40 years $(60.3 \%)$, where $57.4 \%$ were male and $42.6 \%$ were female. Thirty-eight patients (55.9\%) had stone on the left side while thirty patients (44.1\%) had stone on the right side. Stone size ranged from 3 to $8 \mathrm{~mm}$. Mean stone size was $5.78 \mathrm{~mm}$. The mean duration of symptoms was 6.1 days and the mean duration of stone expulsion was 7 days.

Out of 68 patients, 55 (80.9\%) spontaneously passed their stone with medical expulsion therapy while $13(19.1 \%)$ did not pass the stone. Total no of the patient with stone size up to $5 \mathrm{~mm}$ were 21 out of which 21 (100\%) passed stone spontaneously and with stone size from $(5.1-8 \mathrm{~mm})$ were 47 out of which $34(72.3 \%)$ passed stone spontaneously whereas 13 (27.3\%) didn't pass. Lower the size of the ureteric stone higher the number of spontaneous expulsion of ureteric stone though it is not statistically significant which is also supported by other studies. ${ }^{4,7,11}$

Fifty-one patients (92.7\%) with normal white cell count passed their stone with medical expulsion therapy while 4 (7.3\%) did not pass. Four patients $(30.8 \%)$ with high white cell count passed stone but 9 (69.2\%) did not pass the stone. The relationship of spontaneous expulsion of stone with medical expulsion therapy and white cell count was statistically significant, ( $p$-value $<0.001$ ) using ANOVA. This finding is supported by the study carried out in Dharan, Nepal 10 though refuted by the study carried out by Sfoungaristos et al. ${ }^{3}$

The relationship of the passage of stone with medical expulsion therapy and the neutrophil percentage was statistically significant ( $\mathrm{p}$-value $<0.001$ ). These findings are also correlated with the other studies. ${ }^{7,9}$ The patients with distal ureteric calculus with normal neutrophil percentage have a high chance of spontaneous expulsion of distal ureteric calculus. Ureter obstruction caused by ureteric stone triggers inflammatory changes in the distal submucosal layer, leading to elevated neutrophil percentage and prevents spontaneous expulsion. In contrast, a study reveals higher the neutrophil percentage higher the rate of spontaneous expulsion of the distal ureteric calculus. ${ }^{3}$ This study emphasized that prolonged inflammation may decrease the ureteral compliance and luminal diameter hindering stone passage.

Forty-seven patients (92.1\%) with normal CRP level passed their stone with medical expulsion therapy while 4 (7.9\%) did not pass. 
Eight (47.1\%) with high CRP level passed their stone while 9 (52.9\%) did not pass. Statistically, a significant association has been found between the normal CRP level with the spontaneous expulsion of distal ureteric calculus ( $p$-value $<0.001$ ). Patients of distal ureteric calculus with normal CRP level have high chances of spontaneous expulsion of stone with medical expulsion therapy. Various studies have supported these findings when the CRP levels were less, ureteral stone removal rates were high, which suggests that conservative management may be preferred when CRP levels are low. ${ }^{6,7,8,9}$

In this study after using ANOVA, we found that patients with distal ureteric stone $\leq 8 \mathrm{~mm}$ with normal CRP level, WBC count and Neutrophil percentage had higher chances of spontaneous expulsion with medical expulsion therapy as compared to those with higher levels.

Appropriate selection of treatment modality for distal ureteric calculus is necessary for its proper management. This study reveals Neutrophil percentage, WBC count CRP levels were predictors for spontaneous expulsion of distal ureteric stone $\leq 8 \mathrm{~mm}$ size. Thus conservative management with medical expulsion therapy can be the effective treatment option for patients with distal ureteric calculus $\leq 8 \mathrm{~mm}$ in size with normal WBC count, CRP and Neutrophil levels whereas other treatment options should be sought for when their levels are elevated.

\section{CONCLUSION}

Prophecy of success rate in the treatment of small distal $(\leq 8 \mathrm{~mm}$ in size) ureteral stones extensively influence the selection of treatment option. Measuring Serum CRP level, WBC count and the Neutrophil percentage is useful for predicting whether spontaneous distal ureteric stone passage will be successful. More aggressive treatment methods should be considered when Serum CRP level, WBC count and Neutrophil percentages are high.

\section{CONFLICT OF INTEREST}

None

\section{SOURCES OF FUNDING}

None

\section{REFERENCES}

1. Dellabella M, Milanese G, Muzzonigro G. Efficacy of tamsulosin in the medical management of juxtavesicalureteralstones. J Urol. 2003;170(6):2202-5. https://doi. org/10.1097/01.ju.0000096050.22281.a7

2. Erturhan S, Erbagcy' A, Faruk Y, Mehmet C, Solakhan M, Sary'ca K. Comparative of efficacy of use of tamsulosin and/or tolterodine for medical treatment of distal ureteral stones. Urol. 2007;69(4):6336. urology.2007.01.009

https://doi.org/10.1016/j.

3. Sfoungaristos S, Kavouras A, Katafigiotis I, Perimenis P. Role of white blood cell and neutrophil counts in predicting spontaneous stone passage in patients with renal colic. B J Urol. 2012;110(8b):E339$45 . \quad$ https://doi.org/10.1111/j.1464410X.2012.11014.X

4. Segura JW, Preminger GM, Assimos DG, Dretler SP, Kahn RI, Lingeman JE et al. Ureteral stones clinical guidelines panel summaryreport on the management of ureteral calculi. The American Urological Association. J Urol. 1997;158(5):1915$21 . \quad$ https://doi.org/10.1016/S00225347(01)64173-9

5. Mellon JK. Kidneys and ureters. In: Williams NS, O'Connell PR, McCaskie AW, editors. Bailey and love's short practice of surgery. $27^{\text {th }}$ ed. Boca Raton, FL: CRC Press. 2017: 1405-7.

6. Hussein AA. Stone expulsion rate of small distal ureteric calculi could be predicted with plasma C-reactive protein. Urolithiasis. 2013;41(3),235-9. https:// doi.org/10.1007/s00240-013-0551-1

7. Park CH, Ha JY, Kim C, Kim KS, Kim B. Relationship between spontaneous passage rates of ureteral stones less than $8 \mathrm{~mm}$ and serum C-reactive protein levels and neutrophil percentage. Korean 
$J$ Urol. 2013;54(9);615-8. https://doi. org $/ 10.4111 / \mathrm{kju} .2013 .54 .9 .615$

8. Angulo JC, Gaspar MJ, Rodríguez N, García-Tello A, Torres G, Núñez C. The value of C-reactive protein determination in patients with renal colic to decide urgent urinary diversion. Urology. 2010;76(2):301-6. https://doi. org/10.1016/j.urology.2009.12.002

9. Kumar A, Agrawal CS, Sah SP, Joshi BR, Gupta M. Stone expulsion rate of small distal ureteric calculus could be predicted with serum C-reactive protein, white cell counts and neutrophil percentage: A prospective study. Journal of dental and medical sciences (ISORJDMS). 2017;16(11):66-70. Available from: https://www.iosrjournals.org/iosrjdms/papers/Vol16-issue11/Version-3/ N1611036670.pdf [Accessed 15th November 2020]

10. Grasso M, Conlin M, Bagley D. Retrograde ureteropyeloscopic treatment of $2 \mathrm{~cm}$ or greater upper urinary tract and minor staghorn calculi. J Urol. 1998;160(2):34651.https://doi.org/10.1097/00005392199808000-00014

11. Tchey DU, Ha YS, Kim WT, Yun SJ, Lee SC, Kim WJ. Expectant management of ureter stones: outcome and clinical factors of spontaneous passage in a single institution's experience. Korean J Urol. 2011;52(12):847-51. https://doi. org/10.4111/kju.2011.52.12.847 